\title{
Why I Publish in “Predatory” Journals-and Why You Should, Too
}

\author{
Burgess-Jackson $\mathrm{K}^{*}$ \\ The University of Texas at Arlington, USA
}

*Corresponding author: Keith Burgess-Jackson, J.D., Ph.D., Associate Professor of Philosophy,
Department of Philosophy and Humanities, College of Liberal Arts, The University of Texas at
Arlington, Box 19527, Arlington, Texas, 76019-0527, USA, Email: kbj4@att.net, kbj@uta.edu

\section{Conceptual Paper}

Volume 3 Issue 4

Received Date: December 18, 2020

Published Date: December 31, 2020

DOI: $10.23880 /$ phij-16000160

\section{Abstract}

This article has two purposes. The first is to explain why, after 38 years of publishing in "reputable" academic journals, I have decided to publish exclusively in what critics call "predatory" journals. The adjective "predatory" is singularly inapt in this context, for the true predators (i.e., exploiters, oppressors, plunderers) are wealthy multinational publishing corporations who treat researchers and authors as slave laborers. The second purpose is to advocate that other academics (especially those in my own discipline of philosophy) follow my lead.

Keyword: Philosophy; Academia; Publishing; Periodicals; Exploitation; Justice; Oppression

\section{Introduction}

predatory (adj.) seeking to exploit or oppress others . .. from Latin praedatorius, from praedator 'plunderer' (New Oxford American Dictionary, 2010: p. 1376 [boldface and italics in original; ellipsis added]).

plunder (v.) take material from (artistic or academic work) for one's own purposes (New Oxford American Dictionary, 2010: p. 1346 [boldface in original]).

The British philosopher R. M. Hare (1919-2002) once told me, in correspondence, that he had "written too much."1 I have heard the same sentiment expressed by others,

1 R. M. Hare to Keith Burgess-Jackson, 16 June 1995. Copy in author's possession. Hare was 76 years old when he wrote this. He continued to write - and publish - until his death, six and a half years later. In my letter to Hare (dated 13 June 1995), to which he was responding, I had proposed writing a critical study of his work. Hare replied: "I hesitate to let you embark on a book about me; I have written too much. But it is a great encouragement to me (which I need) that anybody should even think of such an undertaking." I have not (yet) written the book I proposed, though I have undertaken work on an annotated bibliography. See here: https://keithburgess-jackson. typepad.com/R.\%20M.\%20Hare\%20\%28Annotated\%20Bibliography\%29. pdf. including British philosopher of education John Boyd Wilson (1928-2003). ${ }^{2}$ Now in my fourth decade as a practicing philosopher, I can't say that I've published too much, but I have published a lot.

My publishing career began in 1982, while I was still a law student at Wayne State University in Detroit, Michigan. I wrote an essay on the topic of suicide for a Legal History course. The professor, Edward M. Wise (1938-2000), wrote to the editors of the Wayne Law Review to recommend publication. All of this was done without my knowledge. In 1982, when I was only 25 years old, my 31-page essay, "The Legal Status of Suicide in Early America: A Comparison with the English Experience" (Burgess-Jackson, 1982), appeared in print. It is one of my proudest achievements. Here I was, a lowly law student whose first-year grades weren't good enough to make law review, and an entire team of first-rate

2 Wilson is the author of more than 30 books, according to the back-cover blurb on at least two of them. His books include Language \& the Pursuit of Truth (1958), Thinking with Concepts (1963), Logic and Sexual Morality (1965), What Philosophy Can Do (1986), and A Preface to Morality (1987). In his letter to me, he wrote, "I write FAR too much and carelessly and feel slightly guilty about it, but glad you find it useful." John Wilson to Keith Burgess-Jackson, 8 July 1988. Copy in author's possession. 


\section{Philosophy International Journal}

students was slaving away on my essay, as though I were an established scholar. I still chuckle at the thought of it.

As of a year ago, I had published 31 stand-alone articles in legal, historical, and philosophical periodicals. ${ }^{3}$ All were either peer-reviewed or reviewed by law students. ${ }^{4}$ I have published in some of the finest periodicals in my discipline: Canadian Journal of Philosophy (twice), Southern Journal of Philosophy, Public Affairs Quarterly (twice), Criminal Justice Ethics, Journal of Social Philosophy (thrice), Philosophy and Rhetoric, Social Theory and Practice (twice), Metaphilosophy, Ethical Theory and Moral Practice, International Journal for Philosophy of Religion (twice), and Journal of Ethics. I have also published a book (on rape) (Burgess-Jackson, 1999) with Oxford University Press, which is one of the world's great publishers of scholarly work. Though I am listed as the editor of the book, I wrote $37 \%$ of its 321 pages, including two substantive chapters: "A History of Rape Law" (17 pages) and "A Theory of Rape" (26 pages).

I say all this not to brag (obviously), but to forestall the objection that I publish in "predatory" journals because I cannot get published in "reputable" journals. In other words, I say this so that nobody thinks I am making a virtue of necessity. My track record as a published author shows that I could continue playing the game for as long as I continue to write. However, I have come to believe that doing so is immoral. I used to think that editors and publishers were doing me a favor by publishing my work. I now believe that I am doing them a favor. How so? By creating the very work from which they so handsomely profit. I do the labor, after all; I put my heart and soul into everything I write. Why should anyone else, especially someone who is already fantastically wealthy, benefit from it? One does not have to be a Marxist to think in these terms. One has only to possess a sense of justice.

My aim in this essay is to explain —in detail—why I now prefer "predatory" journals to "reputable" journals. ${ }^{5}$ Along

3 I publish in legal and historical periodicals because I have credentials in those disciplines. My credentials are as follows: A. B. (Political Science), The University of Michigan-Flint; M.A. (History), Wayne State University; J.D. (Law), Wayne State University; M.A. (Philosophy), The University of Arizona; and Ph.D. (Philosophy), The University of Arizona.

4 Most legal periodicals (known as "law reviews") are edited by students, not professors. The students who edit these periodicals have three tasks: "selection [of articles], improvement, and editing" (Posner, 1995: p. 1132).

5 One may wonder why I use the word "predatory" to describe the journals that I defend, since I don't believe that they're predatory. (In my view, as I explain in a subsequent section, the truly predatory journals are those that I refer to as "reputable," and the truly reputable journals are those that critics refer to as "predatory.") Careful readers will have noticed that I don't use the word "predatory"; I mention it. That is why I enclose the word in quotation marks throughout the essay when describing the journals that I defend. I don't want my readers to think that I'm trying to gain a rhetorical the way, I hope to persuade some of you (my readers) to join me. The essay is divided into several sections, in each of which I set out a reason to opt out of the system that allows the wealthy and powerful (the "haves") to plunder the work of those who are less wealthy and less powerful, if not downright poor and powerless (the "have nots"). These sections are followed by a section in which I explain, at some length, why "predatory" journals are not, in fact, predatory. The real predatory journals are those that I call "reputable." I then discuss (briefly) the classic conflict between morality and self-interest, urging readers who are persuaded by my reasoning to do the right thing, which, in this case, is boycotting "reputable" journals.

\section{Audience}

Writers want to be read. Indeed, it would not be an exaggeration (or much of one) to say that writers need to be read. A writer without an audience is a diarist. The larger the audience, the better. The "predatory" journals in which I now publish are called "open-access." This means that they are accessible to everyone, anywhere in the world, or at least to everyone who has an Internet connection. Most "reputable" journals are not open-access. They are hidden behind paywalls. This means that only those who pay a feeor work for an organization (such as a university) that pays the fee-have access to them. The fees are often prohibitive.

The number of open-access journals is increasing. ${ }^{6}$ This is a good thing. It allows authors to reach a larger audience, including, but not limited to, members of their own disciplines. I don't know for sure how many people have read my essays in "reputable" journals, but I know exactly how many people have read my articles in "predatory" journals. My essay, "How to Prevent School Shootings and Other Mass Homicides," which was published in Beijing Law Review on the final day of 2019 (less than a year ago, as I write this), has been downloaded 222 times and viewed 1,886 times. (It is available in PDF format via download and in HTML format for viewing and reading on the journal's website.) My essay, "The Whole Truth About Partial Truth Tables,"

advantage by describing these journals as, say, "civilized" or "respectable" or "non-exploitative."

In this regard, I follow Don Marquis (1989), who, in his famous essay, "Why Abortion Is Immoral," uses the term "anti-abortion" rather than "pro-life" to describe those who share his view. Actually, he goes further than this. He uses his opponents' preferred term, "pro-choice," to describe his opponents' view, but not his own side's preferred term, "pro-life," to describe his own side's view. I do the same. I describe the journals that I defend as "predatory" (which is derogatory) and the journals that I reject as "reputable" (which is laudatory). Nobody can accuse Marquis-or me-of using manipulative rhetoric to "win" an argument.

6 The Healey Library of the University of Massachusetts-Boston lists 12 peer-reviewed open-access philosophy journals. See here: https://umb. libguides.com/c.php?g=350815\&p=2468261. 
which was published in Open Journal of Philosophy on 8 May 2020, has been downloaded 250 times and viewed 1,070 times. My essay, "Famine, Affluence, and Hypocrisy," which was published in Philosophy Study on 30 July 2020, has been viewed 748 times in less than five months. (There are no figures for downloads.) It is gratifying to know that my work is being read (though, in the nature of things, I can't be sure that it's being studied). I suspect that some of my publications in "reputable" journals have been read by only a few people who happen to have institutional access to those journals.

Publication is costly, and that's why it's not free. Someone has to pay the expenses involved in typesetting and copyediting an essay and maintaining the website where the essay appears. In an open-access system, these expenses are paid by authors (or those who sponsor authors). The fee, known as an Article Processing Charge, or APC, ${ }^{7}$ varies depending on the publication, the length of the essay, and other factors. APCs are made known in advance. Prospective authors can determine how much they will need to pay by visiting a journal's website. If you believe that a particular APC is excessive, you are free to go elsewhere. What you can't do is complain about "hidden" fees, for they are not hidden.

Open-access publishing can be mandatory or optional, in the following sense. Some journals tell authors that they must pay an APC in order to publish there. Some, however, make open access optional. For example, visitors to the website of the journal Studies in History and Philosophy of Science (published by Elsevier) are told that "This journal offers authors two choices to publish their research." The following options are then provided (under the heading "Open[-]access options"):

\begin{tabular}{|c|c|}
\hline Gold Open Access & Subscription \\
\hline Articles are freely & Articles are made available \\
available to both & to subscribers as well as \\
subscribers and the & developing countries and \\
wider public with & patient groups through our \\
permitted reuse. & access programs. \\
\hline An open[-]access & No open[-]access publication \\
publication fee is & fee. \\
payable by authors or \\
their research funder.
\end{tabular}

Many "reputable" open-access journals, such as the aforementioned Studies in History and Philosophy of Science, have APCs, so it cannot be an objection to "predatory" journals in particular that they have APCs. Here are just a few "reputable" open-access journals, with their respective

7 Some journals call it an Article Publishing Charge, with the same acronym.
APCs: ${ }^{8}$

\begin{tabular}{|c|c|c|}
\hline Journal & Publisher & APC \\
\hline $\begin{array}{c}\text { Open Philosophy } \\
\text { De Gruyter }\end{array}$ & $\$ 598.30$ \\
\hline $\begin{array}{c}\text { Philosophical Studies } \\
\text { (Optional) }\end{array}$ & Springer & $\$ 2,750$ \\
\hline $\begin{array}{c}\text { Australasian Journal of } \\
\text { Philosophy (Optional) }\end{array}$ & $\begin{array}{c}\text { Taylor \& } \\
\text { Francis }\end{array}$ & $\$ 2,995$ \\
\hline $\begin{array}{c}\text { Studies in History and } \\
\text { Philosophy of Science } \\
\text { (Optional) }\end{array}$ & Elsevier & $\$ 3,360$ \\
\hline $\begin{array}{c}\text { Philosophy and } \\
\text { Phenomenological Research } \\
\text { (Optional) }\end{array}$ & $\begin{array}{c}\text { John Wiley \& } \\
\text { Sons }\end{array}$ & $\$ 2,500$ \\
\hline
\end{tabular}

An APC, as the name implies, is designed to defray (or cover) publication expenses. Here is how De Gruyter, the publisher of Open Philosophy (not to be confused with Open Journal of Philosophy), justifies its fee: "Regular fee for publishing an article in Open Philosophy is € 500 (+ VAT, if applies). It is used to cover the costs of the peer-review process, professional typesetting and copyediting, as well as online hosting, long-term preservation, distribution to libraries and content aggregators worldwide, and extensive promotion to potential readers."

If you want a large audience, open access is the way to go.

\section{Publication Speed}

Writers want their work not merely to be published, but to be published as soon as possible after it is completed. The sooner one's work appears in print, the sooner it can be engaged by readers. To a philosopher in particular, engagement is everything, since philosophy consists of argument and counter-argument, objection and reply, analysis and criticism. It's why David Hume was so disappointed with the reception of his Treatise of Human Nature (1739-1740): it failed to engage his intended audience..$^{10}$ To adapt the proverbial philosophical question:

8 All of the information contained in this chart was gleaned from the journals' websites.

9 This quotation is taken from a document posted on the website of Open Philosophy.

10 Hume wrote: "Never literary attempt was more unfortunate than my Treatise of Human Nature. It fell dead-born from the press, without reaching such distinction, as even to excite a murmur among the zealots" (Hume, 


\section{Philosophy International Journal}

"If an article is published and nobody reads it, does it make a difference?"

The speed with which "reputable" journals review manuscripts is frustrating to the point of being infuriating. I've waited as long as six months for a publication decision, only to have my manuscript rejected. Since almost all journals require exclusive consideration of manuscripts, a rejection means starting over at square one. Two or three rejections prior to acceptance can mean that more than a year passes between initial submission and publication. I hope that I am not being dramatic when I say that that is obscene.

This isn't even the worst-case scenario. On more than one occasion, so much time has elapsed without a publication decision that I withdrew my manuscript from consideration (prior to sending it elsewhere). One wonders how it could possibly take two, three, four, or six months to read and evaluate a manuscript, even a manuscript that runs to 8,000 or 10,000 words. One also wonders why someone would agree to review a manuscript but then set it aside for several weeks (or months). I agree to review manuscripts only when I can read them right away, and once I agree, I do everything I can to read them right away. Isn't this what a responsible person does? Isn't this a minimal requirement for calling oneself a professional? This is but one way in which academic authors are abused by "reputable" journals.

The time lag between submission and decision is far less for "predatory" journals than it is for "reputable" journals. I have received a decision on a submission to a "predatory" journal in a matter of days, and never more than two weeks. It might be said that this shows that the review process is a sham. Perhaps it is, but as I argue below, the so-called gatekeeping function of "reputable" journals is vastly overrated. More often than not (at least in my experience, which includes talking to other academics), the reviewers at "reputable" journals evaluate the essays they read on the basis of irrelevancies such as whether they "like" the conclusion of the essay, whether they think the topic is "hot" (or "important"), or whether they find the essay's style, methodology, or approach to the topic congenial.

Yes, I am going there: I shall argue in a subsequent section that the gatekeeping function of peer review has devolved into a policing function in which reviewers and editors conspire to "punish" authors for taking politically, morally, or religiously incorrect stands on various issues. In other words, journal editing and reviewing has become politicized. If I am right about this, and I believe I am, then there is good reason to boycott "reputable" journals. They do not deserve the respect and support that they so mindlessly

1777: pp. 7-8 [italics in original]). receive from scholars.

\section{Length}

If your essay exceeds 10,000 words, as several of mine do, ${ }^{11}$ you may have trouble getting it published by a "reputable" journal. American Philosophical Quarterly has a limit of 7,000 words. The Journal of Philosophy has a limit of 7,500 words. Mind, Metaphilosophy, and Australasian Journal of Philosophy have limits of 8,000 words. The "predatory" journals with which I have dealt (such as Open Journal of Philosophy and Philosophy Study), have no word limits-or at least their editors haven't complained about excessive length. Admittedly, many "reputable" journals have limits that exceed 10,000 words (Ethics, for example, has a limit of 15,000 words, and Philosophy and Public Affairs 12,000), so length of publication is not as strong a reason as some of the others that I provide to prefer "predatory" journals to "reputable" journals. Think of it as one factor among many.

\section{Retaining 0wnership}

If you wish to retain the copyright of your creative work, you should consider open access, whether it's with a "predatory" journal or a "reputable" journal. Here is a typical policy for a subscription journal that has no open-access option:

Authors will be asked, upon acceptance of an article, to transfer copyright of the article to the Publisher. This will ensure the widest possible dissemination of information under copyright laws. ${ }^{12}$

Here is a typical policy for an open-access journal:

Open Access authors retain the copyrights of their papers, and all open access articles are distributed under the terms of the Creative Commons Attribution License, CC BY (or the Creative Commons AttributionNonCommercial License CC BY-NC), which allows users to (noncommercially) copy, use, distribute, transmit and display the work publicly and to make and distribute derivative works, in any digital medium for any responsible purpose, subject to proper attribution of authorship. $^{13}$

\footnotetext{
11 My article, "How to Prevent School Shootings and Other Mass Homicides" (Burgess-Jackson, 1999), runs to 12,113 words. My article, "The Whole Truth About Partial Truth Tables" (Burgess-Jackson, 2000a), runs to 11,819 words. My article, "Famine, Affluence, and Hypocrisy" (BurgessJackson, 2000b), runs to 11,957 words. The present article will run to slightly over 9,000 words.

12 From the website of Law and Philosophy, which is published by Springer.

13 From the website of Open Journal of Philosophy, which is published by Scientific Research Publishing.
} 


\section{Philosophy International Journal}

Here is a typical policy for a subscription journal that has an open-access option:

For subscription articles: Authors transfer copyright to the publisher as part of a journal publishing agreement. ...

For open access articles: Authors sign an exclusive license agreement, where authors have copyright but license exclusive rights in their article to the publisher. $\ldots^{14}$

As I have said, some "reputable" journals offer an openaccess option, so the most I would wish to say on this score is that most "predatory" journals offer open access, while only some "reputable" journals do. I should also point out that there are advantages as well as disadvantages to transferring one's copyright. My point is simply that you will be allowed to retain your copyright at most "predatory" journals. Copyright is property. Your property.

\section{Bypassing Biased, Obtuse, or Obnoxious Editors (and Referees)}

If you have ever dealt with a biased or obtuse journal editor, or with referees who have axes to grind, the following story will resonate with you. Many years ago, I submitted a manuscript entitled "Taking Egoism Seriously" to a prominent philosophical periodical, which I will not name here. Almost immediately, the editor of the periodical replied, by e-mail. He said (and here I paraphrase from memory) that egoism is a false normative ethical theory and that he would not, therefore, be sending it out for review.

I was stunned. It's not as though this topic had never been treated in the periodical in question, because it had. Nor was it that my essay was too long or obviously unacceptable on account of its organization or writing style. I suspect that the editor hadn't even read beyond the essay's abstract, in which I signaled my intention to (1) take egoism seriously and (2) advocate that my philosophical colleagues do the same. The editor was obviously biased against egoism, and he didn't want to sully his precious periodical with an essay on that topic.

It occurred to me upon receiving the editor's e-mail that, had he received an essay on libertarianism written by Robert Nozick (1938-2002), ${ }^{15}$ entitled, say, "Taking Libertarianism Seriously," he would have made the same reply. Other editors

14 From the website of Studies in History and Philosophy of Science, which is published by Elsevier.

15 Nozick is the author of Anarchy, State, and Utopia (Nozick, 1974), one of the great works of political philosophy of the 20th century. may have done so as well, to the point where Nozick had no alternative but to put the essay aside as unpublishable. Wouldn't that be a loss to the discipline? Within the cloistered ranks of academic philosophy, libertarianism is no more popular as a normative political theory than egoism is as a normative ethical theory. Would the editor in question have replied to Nozick that libertarianism is a false normative political theory, and therefore not to be defended in the august pages of his journal? One suspects so, and that's frightening. No editor should be so imperious as to dictate which views are true and which false, which views are wellfounded and which ill-founded, which theories are worth considering and which not.

I am well aware that some people view philosophy as a search for truth. On any given issue, they maintain, there are, initially, several views. Over time, views get disproved. When this occurs, the views in question get dropped from the conversation. Anyone who tries to bring them up will be seen as trying to revive the dead, which is of course pointless. This is not my view of philosophy at all. No view ever gets disproved, if only for the reason that new and interesting arguments may be constructed in its favor. Viewed this way, ethical egoism is alive and well and should continue to be discussed in the philosophical literature. (I'll go further than this: It will always be alive and well, for as long as there are human beings.) Lest you think that my essay was rejected for lack of merit, I hasten to point out that it was accepted for publication right away by a very good journal, Ethical Theory and Moral Practice. The editor of that journal was not biased like the editor of the first journal. Perhaps you will want to read my essay for yourself to determine whether the first editor's bias led him to make a mistake. Unfortunately, it's behind a paywall, so I hope you have institutional access to it.

I wish I could say that this has been my only experience with biased, obtuse, or obnoxious editors. It is not. A year or so ago, I submitted an essay entitled "How to Prevent School Shootings and Other Mass Homicides" to a prominent philosophical periodical. I had worked on this essay for over a year and had polished it to (what I considered) gemlike status. I still consider it to be one of the best things I've written in my career, and also one of the most important, practically speaking. Here is the abstract:

Mass homicides, of which school shootings are a species, are all too common. What makes them philosophically interesting is that the usual punishments for such crimes are ineffective. How does one deter a person who is intent on killing himself or herself upon completion of the massacre? After clarifying the concepts of prevention, deterrence, and punishment, I describe various modes of punishment. If we are serious about preventing mass homicides, we must not rule out any mode of 


\section{Philosophy International Journal}

punishment a priori. I suggest several punishments, such as torture and imprisonment with hard labor, that may deter prospective mass murderers. The aim is to find a punishment that the prospective mass murderer fears more than death. I also recommend the inculcation of theism (understood as belief in a retributive god) as a means of deterring mass homicides.

Well! This essay met a wall of resistance. It was rejected several times, often without being sent for review. For the life of me, I don't know why. I have never had trouble finding an outlet for my philosophical work. ${ }^{16}$ My suspicion in this case, based on certain comments that I received from editors and reviewers, is that One Must Not Defend (or even say anything favorable about) Torture. Only one view on that topic is acceptable, evidently, and that is resolute opposition. ${ }^{17}$ After the fourth or fifth rejection, I concluded that no "reputable" journal was going to publish my essay. I eventually sent it to the Beijing Law Review (which some people consider a "predatory" journal), where it was accepted (and published) in short order. This is when I began to think seriously about boycotting "reputable" journals. I have little tolerance for stupidity, and none whatsoever for bias, especially in a discipline (philosophy) that prides itself on fearlessness, boldness, and open-mindedness.

Not to belabor the topic, but there is another problem with editors and reviewers besides bias, and that is clubbiness (which may be thought of as a form of personal bias). Several months ago, I completed a long essay entitled "Famine, Affluence, and Hypocrisy," on which I had worked, off and on, for several years. Here is the abstract:

The standard view among philosophers is that an arguer's hypocrisy (understood as failure to practice what one preaches) has no bearing on either the merits of his or her argument or the acceptability of the argument's conclusion. I challenge this view. Using the case of Peter Singer, who has famously argued for a moral obligation to relieve famine, but who does not, by his

16 From 1988 to 2003, I was a feminist (indeed, a radical feminist). During these years, I published with ease in "reputable" journals. Since becoming a conservative in 2003, I have struggled to get certain essays published. Either (1) I have become a worse writer or reasoner over the years or (2) editors and reviewers make decisions based on the positions taken by authors rather than on the merits of the work under review. I'm fairly sure that I have not become a worse writer or reasoner over the years.

17 Philosophers tend not to be absolutists, but several prominent philosophers have argued in recent years for an absolute ban on torture (including interrogational torture, in which the goal of authorities is to secure information that will save innocent lives). See, e.g., Shue, 2005; Waldron, 2005; Mayerfeld, 2008; and Juratowitch, 2008. It is interesting to note that some of the same philosophers who support an absolute ban on interrogational torture oppose an absolute ban on killing the innocenteven on killing innocent babies. For more on the opposition to torture, see Section 8 of my published essay. own admission, live in accordance with the standard he espouses, I explain why (and how) an arguer's hypocrisy matters. If I am correct, then the standard view of the relation between arguer and argument must be revised.

Maybe I'm naïve, or even narcissistic, but I thought that this was a pathbreaking essay that would stimulate philosophical debate for years to come. For one thing, I was challenging a long-standing philosophical dogma (about the irrelevance of an arguer's personal qualities to the merits or acceptability of his or her argument). For another thing, I was providing an original taxonomy of hypocrisy that not only distinguished three types of hypocrisy but explored their logical inter-relations. Anyone who lacked interest in Peter Singer-my example of a hypocrite-could easily skip the section in which I document his hypocrisy. (In case you're wondering, he is a hypocrite of all three types.)

I was shocked and disappointed by the essay's reception. Time and time again, over a period of many months, it was rejected, sometimes within a matter of days of submission. The quick rejections told me that it failed to pass initial review by the editor. Why? I can't be sure, but I believe it's because I used Peter Singer as my example of a hypocrite. Singer is a revered figure in philosophy, and has been for almost half a century. I documented in meticulous detail Singer's failure to live up to the high moral standard he pronounces in his essays and books on famine relief. As I explain in the essay, I used to tell my students that Singer's hypocrisy (such as it is) is irrelevant to the merits or acceptability of his argument; but now I believe otherwise. The purpose of the essay is to show exactly why, and how, Singer's hypocrisy matters.

Think about it. Would you want to be the editor who publishes an essay in which a beloved member of your club is portrayed (however accurately) as a hypocrite? How would that affect your career? Many readers of this journal will know this already, but I have nowhere near the stature or influence of Singer, in or out of philosophy. An editor may have thought that my essay was a hit piece, or, at a minimum, that it was insensitive to or insulting toward a colleague. But Singer's hypocrisy is a matter of public record. Indeed, he admits in many places-always with a note of resignation and with a vow to do better-that he fails to live up to his high moral standard. All I did is collect his pronouncements and place them alongside well-known facts about his life and behavior. I could have used a hypothetical example, to be sure, but sometimes a real example drives home the point in a way that a made-up case never does, or could. I honestly cannot think of a better (and more well-documented) example of a hypocrite than Peter Singer.

After several rejections of my essay, and with increasing dismay, I decided to submit it to a "predatory" journal. I was 


\section{Philosophy International Journal}

tired of playing a losing game and wanted to get the essay "out there" and out of my hands. If you would like to read it, visit the website of Philosophy Study. Make up your own mind about its merits. Even if you disagree with me that an author's hypocrisy is relevant to the acceptability of his or her argument (and if you do, I would like to hear from you), you may find my taxonomy of hypocrisy illuminating and useful. I should add that I dedicated the essay to Peter Singer. I have learned much from him over the years, and even corresponded with him a few times on various topics (including famine relief). I like and admire Peter Singer. I believe that he has done more good for non-human animals than any other philosopher, past or present. I do, however, wish that he would stop preaching about famine relief if he cannot practice what he preaches. His hypocrisy, in my judgment, is doing real harm to the profession of philosophy. To see why, read the essay.

So far, I have been talking about editors. Let me now say a few words about reviewers (or referees). What I am about to say may be shocking, but I have never received a useful comment from a reviewer-in nearly four decades of publishing. When an essay of mine is accepted, very often I am told by the editor to accommodate the reviewers' suggestions (or, as the case may be, to reply to the reviewers' objections). I do so, but only to ensure that the essay gets published. Sometimes, to put it bluntly, the reviewers' comments are stupid. Because my experience with reviewers' comments is so bad, I wonder whether the practice of having reviewers submit comments and suggestions should be discontinued. Shouldn't the role of the reviewer be (simply) to give a thumb's up or thumb's down? If the reviewer has comments, shouldn't they be published as a reply to the essay? I'm serious about this. Either the essay is publishable as it is or it is not. If it's not publishable, then the reviewer should recommend rejection. If it's publishable, then the reviewer should say so and let it go at that. What I don't understand is a reviewer saying that an essay is publishable, but only if certain changes are made.

It will be said that this is crazy. "Essays benefit from constructive criticism. The more constructive criticism, the better." This may be true for some people, but it's not for me. By the time I submit an essay for publication, I have worked it over for months, writing, re-writing, and re-writing again. I rarely ask for feedback from anyone, which is why you find dedications to my dogs and to deceased friends and relatives - rather than expressions of thanks to colleaguesin my published articles. Some writers do not need help. When we submit our work for publication, it is because we believe it to be ready for publication. We do not appreciate (or expect) criticism, constructive or otherwise. I especially do not like criticism (however well-intended) from people who have only skimmed my essay, and that, sadly, appears to be the case most of the time.

To bring this discussion back to where it began, one reason to prefer "predatory" journals to "reputable" journals is that the editors and reviewers of "predatory" journals have a light touch, as compared to the editors and reviewers of "reputable" journals. They respect their authors. I like this. When I complete an essay to my satisfaction, I expect it to be published as is or not at all. Nobody has to read it, after all, and those who do read it are free to disagree with anything I say. They are even free to write a reply and send it to me, telling me what they think. They are even free to publish a reply, either in the same journal or somewhere else. That, to me, is the publishing ideal. It is why, going forward, I shall publish only in "predatory" journals. I no longer even submit my work to "reputable" journals.

\section{Scholarly Independence}

exploitation Originally the term has [sic] no moral connotations, referring simply to the use or development of resources. In moral and political philosophy it now applies specifically to the unjust economic and social relationships whereby one class can abuse the labour of others. To characterize a relationship as exploitative thus presupposes a negative moral verdict on its justice (Blackburn, 2008: p. 126 [boldface in original]).

I have now provided several independent reasons to publish in "predatory" journals. Each reason is explanatory, in the sense that it explains why $I$, the author of this essay, publish in "predatory" journals; but each is also justificatory, in the sense that it provides a reason for anyone elseanyone who happens to read this essay, including you-to follow my lead.

The best reason I can think of to publish in "predatory" journals is that the alternative, publishing in "reputable" journals, is exploitative, and therefore unjust. Let me explain what I mean by this. According to British journalist George Monbiot, writing in 2018,

Half the world's research is published by five companies: Reed Elsevier, Springer, Taylor \& Francis, Wiley-Blackwell and the American Chemical Society. Libraries must pay a fortune for their bundled journals, while those outside the university system are asked to pay $\$ 20, \$ 30$, sometimes $\$ 50$ to read a single article (Monbiot, 2018).

In 2019, Reed Elsevier (now known as Elsevier) had net income of $\$ 2.58$ billion. It publishes 2,500 journals. Taylor \& Francis is now a division of Informa plc, which had net income of $\$ 330.4$ million in 2019. Wiley-Blackwell, now known as John Wiley \& Sons, or Wiley for short, had revenue 


\section{Philosophy International Journal}

of $\$ 1.7$ billion in 2017. It publishes 1,600 journals..$^{18}$ Imagine someone contemplating these figures and exclaiming:

Let me get this straight. I slave away every day, for months on end, writing this essay. When it's done, I submit it to a journal for publication. If I'm lucky enough to get it accepted, I must transfer my copyright to a fabulously wealthy multinational publishing conglomerate, which promptly publishes the essay and puts it behind a paywall. From that point forward, the only people who can read my essay are those who pay for access to it, or who work for someone who pays for access to it. I get no money for my labors, though I do get a line on my curriculum vitae. How does this differ from being a slave?

Not all journals are owned by rich corporations, but many are. Philosopher Mark Colyvan has compiled a list of the "top 50" philosophy journals, broken up into two groups: the 25 best general-philosophy journals and the 25 best specialist journals. ${ }^{19}$ Ten of the 50 journals are published by Wiley, 10 by Springer, two by Taylor \& Francis, two by Brill (net income in 2019 of $\$ 2.62$ million), and one by Elsevier. Eight are published by Oxford University, which, as of 2017, had consolidated net assets of $\$ 11.89$ billion. Four are published by Cambridge University, which, as of 2017, had consolidated net assets of $\$ 15.59$ billion. ${ }^{20}$ That's 37 of 50 journals published by obscenely wealthy corporations, and several of the remaining 13 are published by equally wealthy-if not wealthier-universities, such as Duke, Chicago, Pennsylvania, Illinois, and Johns Hopkins.

If you submit your essay to a "reputable" journal that is owned by one of these wealthy corporations (and most of them are), you are participating in an exploitative (hence unjust) system. If, like me, you refuse to be exploited (treated unjustly), and if, also like me, you refuse to participate in a system that exploits others, you will consider submitting your work to "predatory" journals.

There is an instructive parallel between this case and the case of unjust systems of agriculture. Lawyer and adjunct law professor Steven M. Wise has argued (Wise, 1986) that factory farms are unjust, and, as such, should be abolished. But working for the abolition of factory farms (i.e., dismantling the factory-farming system, in which animals are treated as little more than inanimate objects for human use and consumption) is not the only thing that conscientious

18 The information in this paragraph is taken from Wikipedia ("the free encyclopedia").

19 See here: http://www.colyvan.com/journals.html.

20 Oxford and its colleges had cumulative net income of $\$ 1.04$ billion in 2017. See Adams \& Greenwood, 2018. I did the currency conversions, using Google. individuals can do. They can also abstain from consuming animal products that originate in factory farms. The idea is not that one's actions will, all by themselves, dismantle the system (though they will play a small role in doing so). It is that one ought not participate in unjust institutions. It's a matter of not dirtying one's hands, morally speaking. It's a matter of practicing what you preach. If it helps, you may think of scholarly publication in "reputable" journals as factory farming of academic researchers and writers. I, for one, will not be farmed. Will you?

\section{Why "Predatory" Journals Are Not Predatory-and Why "Reputable" Journals} Are

I explained in footnote 5 why I refer to certain journals as "predatory" and others as "reputable." I don't really believe that the journals I call "predatory" are predatory. In fact, I believe that the journals I call "predatory" are reputable and that the journals I call "reputable" are predatory. (There may be exceptions to each of these claims.) The critics of the journals that I defend in this essay are engaged in what philosophers call "persuasive definition." It is a rhetorically manipulative tactic used by those who cannot win an argument honestly.

Let us begin with some lexical definitions. A predator (noun) is "a person or group that ruthlessly exploits others" (New Oxford American Dictionary, 2010: p. 1376). To prey (verb) is to "take advantage of; exploit or injure" (New Oxford American Dictionary, 2010: p. 1385). Prey (noun) is "a person or thing easily injured or taken advantage of" (New Oxford American Dictionary, 2010: p. 1385). I hope I have made it clear, in my discussion of scholarly independence, that multinational publishing conglomerates take advantage of academic researchers and writers. For one thing, these conglomerates require, as a condition of publication, that the researchers and writers transfer their copyright. The creator of the work loses ownership and control of it. No money is paid for this valuable commodity, and yet the conglomerate earns a great deal of money by selling it to libraries. If this doesn't constitute ruthless exploitation, I don't know what does.

The concept of predation connotes not just a hungry aggressor, but a hapless-and comparatively defenselessvictim. This is precisely what one finds in academia, especially among young, untenured professors. What are such professors to do? If they hope to earn tenure, and later promotion to full professor, they must publish in what their disciplines consider "reputable" journals. But these are precisely the journals that prey on them-that take advantage of their vulnerability. As former editor Richard 


\section{Philosophy International Journal}

Smith puts it, "It would be a bold or foolish academic who declined to publish in the top journal because it was too expensive or owned by a rapacious publisher" (Smith, 2006: p. 454). George Monbiot concurs:

While open-access journals have grown rapidly [in number], researchers still have to read the paywalled articles in commercial journals. And, because their work is assessed by those who might fund, reward or promote them according to the impact of the journals in which they publish, many feel they have no choice but to surrender their research to these companies (Monbiot, 2018).

Are the journals that I call "predatory" truly predatory in the ways described? Some people believe they are. Bradley Allf, a graduate student in conservation biology at North Carolina State University, recently published a short essay (Allf, 2020) in an online publication in which he set out to "demonstrate" that at least some "predatory" journals publish "junk science." I am not interested here in the ethics of defrauding publishers, as Allf clearly did when he submitted his bogus essay. (Does the end justify the means?) What interests me is his use of the term "predatory" to describe certain journals. Allf uses the term "predatory" 12 times in his essay, contrasting so-called predatory journals with "legitimate" journals. He uses terms like "scam," "masquerading," "menace," "fraud," "posing," "duped," "bogus," and "fake," but without ever explaining what is wrong with a contractual relationship between an author and a publisher. ${ }^{21}$

If the journals Allf calls "predatory" are taking advantage of someone, then it should be easy for him to support (and document) that claim. Was someone misled? If so, how? Were the terms of the agreement oppressive, unconscionable, or otherwise objectionable? If so, in what way? Was pressure exerted by the publisher? If so, what type of pressure was it, and how was it experienced by the author? Using pejorative terms to describe what one condemns is not argumentation; it is name-calling. In fact, it is worse than name-calling. It is manipulative rhetoric designed to secure agreement without doing the hard work of argumentation.

Let me explain in some detail the particular type of manipulative rhetoric that I have in mind. The word

21 Allf appears to be unaware of the fact that many journals that he would consider "legitimate," such as those listed in a previous section of this essay, have open-access options for which they charge authors great sums of money (as an APC). He writes: "In the niche world of academic publishing fraud, these groups [i.e., "predatory" journals] make money by posing as legitimate scientific journals, publishing anything they get their hands on, and then charging authors hundreds or even thousands of dollars in processing fees" (emphasis added). Does Allf not realize that all journals, in or out of science, "make money"? "predatory," as used in connection with human beings and human institutions (as opposed to animals), is pejorative. Nobody wants to be, or to be seen as, predatory. When one describes a human being or human institution as predatory, therefore, one is condemning it. The condemnation is built into the meaning of the word, as it were. This fact about language can be exploited by the unscrupulous. If I wish for my interlocutor to form an unfavorable opinion of something that he or she does not already have an unfavorable opinion of, I will apply the label "predatory" (or some other negatively charged label) to it in the hope that the negativity of the word transfers to the thing itself. ${ }^{22}$

Perhaps an example from another context will make this clear. The term "rape" is defined in the law as "Unlawful sexual intercourse with a female without her consent" or "The unlawful carnal knowledge of a woman by a man forcibly and against her will" (Black's Law Dictionary, 1979: p. 1134). The key elements in these definitions are "without her consent" and "forcibly and against her will." Suppose I have a negative attitude toward unwanted sex (as such). I may describe it as "rape," hoping thereby to manipulate my interlocutor(s) into forming a negative attitude toward unwanted sex. But unwanted sex is not rape. ${ }^{23}$ The law has never defined "rape" as unwanted sex. A particular sex act that is "unwanted" by a woman may not rise to the level of rape, as that term is understood in the law. ${ }^{24}$

This process of applying a negative (or positive) term to something to which it (the term) does not, strictly speaking, apply, with the aim of changing someone's opinion about that thing, is called "persuasive definition." ${ }^{25}$ It is what those who use the term "predatory" are doing when they describe certain journals as predatory. They are trying to induce their interlocutors to form a negative attitude toward those journals, not by arguing on the merits (which is respectful and reputable) but by using manipulative rhetoric (which is disrespectful and disreputable). Persuasive definition goes against everything philosophy stands for. Its use is a sign that the user cannot make a rational case for the proposition in question-in this case, that certain journals are bad (in some sense) or unworthy of academic patronage. The irony, of course, is that some of the terms used by Allf

22 One can also engage in persuasive definition with laudatory words, such as "democracy," "justice," "equality," "liberty," and "marriage." The aim is to get people to think favorably of things to which the terms do not, strictly speaking, apply.

23 Each of us does things every day that we don't want to do. We do these things grudgingly or reluctantly, perhaps even resentfully. For example, I don't want to go to work today. This doesn't mean that if I go, I do so "without consent." Nor does it mean that I am "forced" to go or that I go "against my will."

24 For further discussion of this point, see Burgess-Jackson, 1995.

25 The locus classicus is Stevenson, 1938. 
to describe what he calls "predatory" journals-terms such as "duped," "bogus," and "fake"-perfectly describe his own argumentative technique.

For the record, I will be first in line to condemn deceptive marketing or any kind of coercion. If a journal engages in deception to secure publishable articles, or pressures authors to publish at that site, it should be called out. Nothing of this sort has occurred in my interactions with "predatory" journals. The opposite is the case. I am treated respectfully (which cannot be said about some of the "reputable" journals with which I have dealt) from beginning to end; I am given all relevant information about the terms of the agreement; and I am offered ample opportunity to review galley proofs prior to publication, in order to correct editorial or typesetting errors. Allf makes it seem as though all or most "predatory" journals engage in sharp business practices or other forms of questionable or immoral conduct. There is no evidence that this is the case, and plenty of evidence that it is not. My experiences to date have been so congenial, in fact, that I look forward to further dealings with "predatory" journals. I am not hapless; I am not defenseless. I am nobody's prey.

\section{Morality and Self-Interest}

By this point in the essay (if you have gotten this far), you may be thinking: "I agree that continuing to publish in 'reputable' journals is morally problematic, if not downright unjust, for the reasons that Burgess-Jackson provides, but doing so is essential for my career. I want to be tenured; I want eventually to be promoted to full professor; I want to be well regarded by my colleagues and peers as I proceed on my scholarly journey. I don't want to be an outcast or laughingstock in my chosen discipline, and I certainly don't want to have to give up (or risk losing) a scholarly career altogether. Publishing in 'predatory' journals is bound to harm my career prospects."

This is the classic conflict between morality and selfinterest. ${ }^{26}$ Unless you are an ethical egoist, you believe that morality and self-interest diverge. This doesn't mean that they always come apart, for they may happen to come together in a particular case (or particular cases); it means that they don't always come together. Sometimes doing the right thing is costly to self. Sometimes acting in one's self-interest compromises, or even violates, one's moral principles. Sometimes, tragically, one can't be both moral and prudent.

Suppose you grew up eating meat. You love its taste and how it makes you feel, but are convinced (by philosophical

26 For illustrative (and in some cases seminal) essays on the topic, see Gauthier, 1970. argumentation of the sort produced by people you admire, such as Peter Singer or Tom Regan) that meat-eating is wrong. Do you continue to eat meat? If you do, you will suffer from cognitive dissonance (not to mention a guilty conscience). The best way to prevent cognitive dissonance while holding on to your moral beliefs is to change your behavior. This is hard to do, especially when the behavior is habitual, but it can be done. If you decide to publish in "predatory" journals and to forgo publication in "reputable" journals, you should, as a form of self-defense, be prepared both to explain and to justify your actions to those above you in the academic hierarchy, such as the chair of your department or the dean of your school or college. This joint exercise in explanation and justification is itself an act of scholarship, not to mention an aspect of academic integrity. It is precisely why I wrote this essay: to explain—and justify—my heretical conduct.

My advice to you? Do the right thing. Fiat justitia, ruat cœlum. ${ }^{27}$ It may not be easy; indeed, it will not be easy. You are up against powerful forces, both academic and economic. The alternative, however, is to participate in an institution that you believe to be unjust-and have reason to believe unjust. Can you live with yourself if you do that?

\section{Conclusion}

Academics are fed up with being ripped off and are proposing different ways of making research available (Smith, 2006: p. 454).

This article has two purposes. The first is to explain why, after 38 years of publishing in "reputable" academic journals, I have decided to publish exclusively in what critics call "predatory" journals. The adjective "predatory" is singularly inapt in this context, for the true predators (i.e., exploiters, oppressors, plunderers) are wealthy multinational publishing corporations who treat researchers and authors as slave laborers. The second purpose is to advocate that other academics (especially those in my own discipline of philosophy) follow my lead.

Acknowledgments: This essay is dedicated to Chloe and Autie, my canine companions of eight years (and counting).

\section{References}

1. Adams R, Greenwood X (2018) Oxford and Cambridge University Colleges Hold $£ 21$ bn in Riches. The Guardian.

2. Allf B (2020) I Published a Fake Paper in a 'PeerReviewed' Journal. Undark.

27 Translation: "Let right be done, though the heavens should fall" (Black's Law Dictionary, 1979: p. 561). 
3. Blackburn S (2008) The Oxford Dictionary of Philosophy. $2^{\text {nd }}($ Rev Edn.), New York: Oxford University Press.

4. Henry Campbell Black MA (1979) Black's Law Dictionary. $5^{\text {th }}$ (Edn.), St. Paul, MN: West Publishing Company.

5. Burgess-Jackson K (1982) The Legal Status of Suicide in Early America: A Comparison with the English Experience. Wayne Law Review 29: 57-87.

6. Burgess-Jackson K (1995) Rape and Persuasive Definition. Canadian Journal of Philosophy 25(3): 415454.

7. Burgess-Jackson K (1999) A Most Detestable Crime: New Philosophical Essays on Rape. New York: Oxford University Press.

8. Burgess-Jackson K (2019) How to Prevent School Shootings and Other Mass Homicides. Beijing Law Review 10: 1409-1430.

9. Burgess-Jackson K (2020a) The Whole Truth About Partial Truth Tables. Open Journal of Philosophy 10(2): 192-219.

10. Burgess-Jackson K (2020b) Famine, Affluence, and Hypocrisy. Philosophy Study 10: 397-413.

11. Gauthier DP (1970) Morality and Rational Self-Interest. Englewood Cliffs, NJ: Prentice-Hall.

12. Hume D (1777) The Life of David Hume, Esq., Written by Himself. London: Printed for Strahan W; and Cadell T, in the Strand.

13. Juratowitch B (2008) Torture Is Always Wrong. Public
Affairs Quarterly 22(2): 81-90.

14. Marquis D (1989) Why Abortion Is Immoral. The Journal of Philosophy 86(4): 183-202.

15. Mayerfeld J (2008) In Defense of the Absolute Prohibition of Torture. Public Affairs Quarterly 22(2): 109-128.

16. Monbiot G (2018) Scientific Publishing Is a Rip-Off: We Fund the Research-It Should Be Free. The Guardian.

17. (2010) New Oxford American Dictionary. $3^{\text {rd }}$ (Edn.). New York: Oxford University Press.

18. Nozick R (1974) Anarchy, State, and Utopia. New York: Basic Books.

19. Posner RA (1995) The Future of the Student-Edited Law Review. Stanford Law Review 47: 1131-1138.

20. Shue $H$ (2005) Torture in Dreamland: Disposing of the Ticking Bomb. Case Western Reserve Journal of International Law 37(2): 231-239.

21. Smith R (2006) The Highly Profitable but Unethical Business of Publishing Medical Research. Journal of the Royal Society of Medicine 99(9): 452-456.

22. Stevenson CL (1938) Persuasive Definitions. Mind 47(187): 331-350.

23. Waldron J (2005) Torture and Positive Law: Jurisprudence for the White House. Columbia Law Review 105(6): 1681-1750.

24. Wise SM (1986) Of Farm Animals and Justice. Pace Environmental Law Review 3: 191-227. 